Nevada

Environmental

Restoration

Project

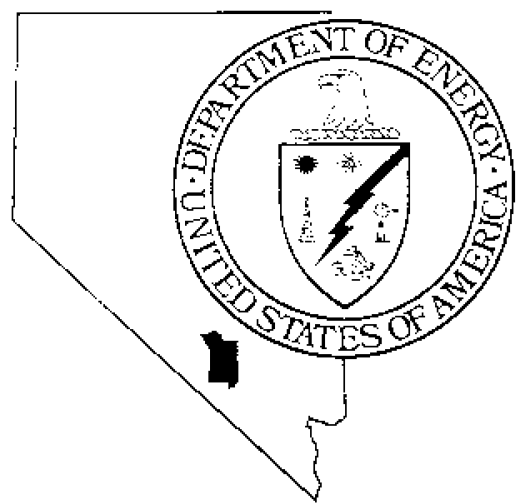

Streamlined Approach for

Environmental Restoration Closure

Report for Corrective Action

Unit 198: Test Cell C

Filter Tank Closure

Nevada Test Site, Nevada

Controlled copy No.

Revision: 0

December 1998

Distribution A - Approved for public release; further dissemination unlimited.

Environmental Restoration

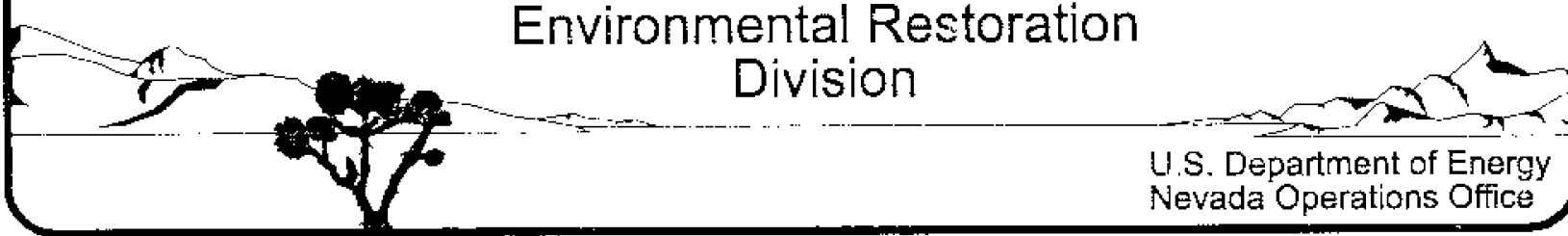


Available to the public from:

U.S. Department of Commerce

National Technical Information Service

5285 Port Royal Road

Springfield, VA 22161

(703) $487-4650$

Available electronically at http://www.doe gov/bridge. Available to U.S. Department of Energy and its contractors in paper from:

U.S. Department of Energy

Office of Scientific and Technical Information

P.O. Box 62

Oak Ridge, TN 37831-0062

(423) $576-8401$

Reference herein to any specific commercial product, process, or service by trade name, trademark, manufacturer, or otherwise, does not necessarily constitute or imply its endorsement, recommendation, or favoring by the U.S. Government or any agency thereof or its contractors or subcontractors. 


\section{STREAMLINED APPROACH FOR ENVIRONMENTAL RESTORATION CLOSURE REPORT FOR \\ CORRECTIVE ACTION UNIT 198: \\ AREA 25 TEST CELL C \\ FILTER TANK CLOSURE \\ NEVADA TEST SITE, NEVADA}

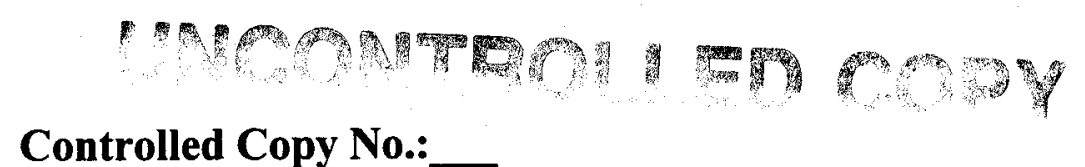

Controlled Copy No.:

Revision: 0

December 1998

Prepared for the

U. S. Department of Energy

Nevada Operations Office

Work Performed Under Contract No. DE-AC08-96NV11718 
THIS PAGE INTENTIONALLY LEFT BLANK 


\section{STREAMLINED APPROACH FOR ENVIRONMENTAL RESTORATION CLOSURE REPORT FOR \\ CORRECTIVE ACTION UNIT 198: \\ AREA 25 TEST CELL C \\ FILTER TANK CLOSURE \\ NEVADA TEST SITE, NEVADA}

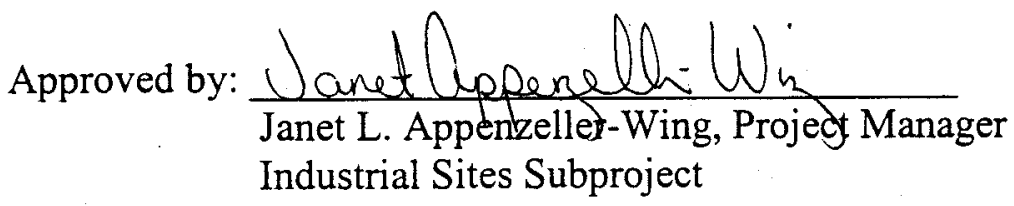

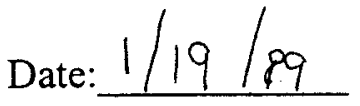

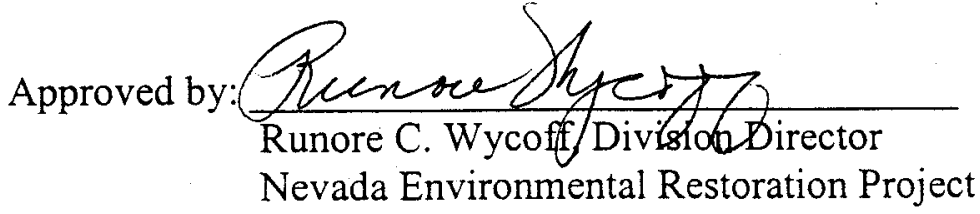

Date: $1-19-99$ 
THIS PAGE INTENTIONALLY LEFT BLANK 


\section{TABLE OF CONTENTS}

ACRONYMS AND ABBREVIATIONS $\ldots \ldots \ldots \ldots \ldots \ldots \ldots \ldots \ldots \ldots \ldots$ vii

EXECUTIVE SUMMARY $\ldots \ldots \ldots \ldots \ldots \ldots \ldots \ldots \ldots \ldots \ldots \ldots \ldots \ldots \ldots \ldots$

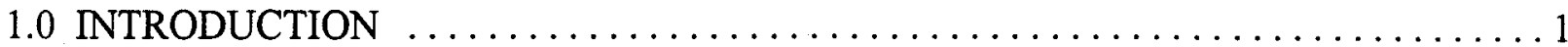

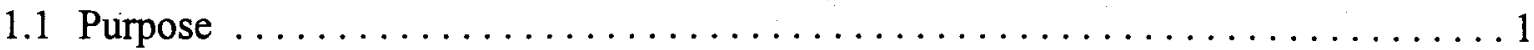

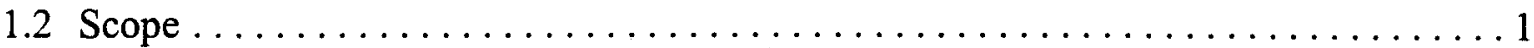

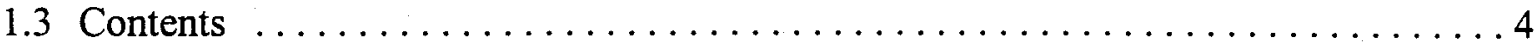

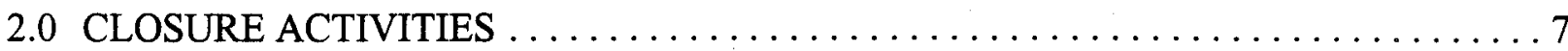

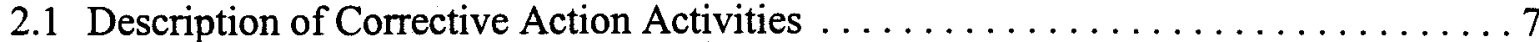

2.2 Deviations from SAFER Closure Plan as Approved $\ldots \ldots \ldots \ldots \ldots \ldots \ldots \ldots$

2.3 Corrective Action Schedule as Completed $\ldots \ldots \ldots \ldots \ldots \ldots \ldots \ldots \ldots$

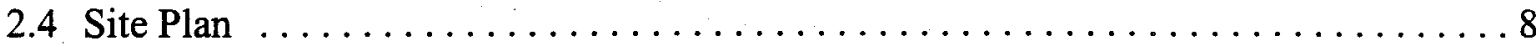

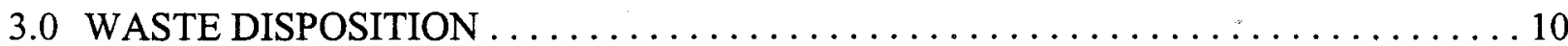

4.0 CLOSURE VERIFICATION RESULTS $\ldots \ldots \ldots \ldots \ldots \ldots \ldots \ldots \ldots \ldots \ldots \ldots \ldots \ldots$

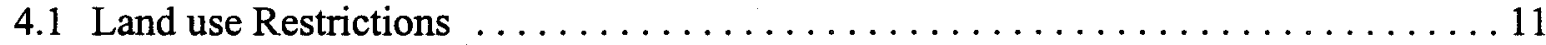

5.0 CONCLUSIONS AND RECOMMENDATIONS $\ldots \ldots \ldots \ldots \ldots \ldots \ldots \ldots \ldots \ldots \ldots$

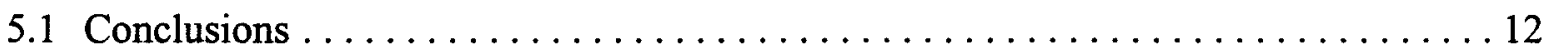

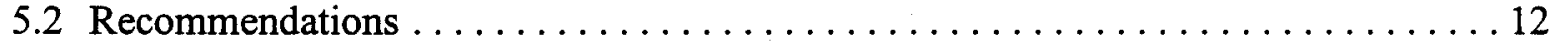

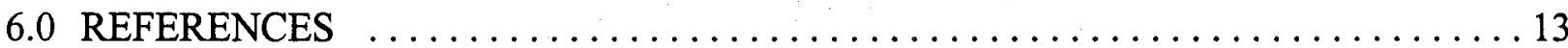

APPENDIX A - RESULTS OF GAMMA SPECTROMETER SURVEY

APPENDIX B - PROJECT PHOTOGRAPHS

APPENDIX C - TEST CELL C FILTER TANK DISPOSAL VERIFICATION LETTER

DISTRIBUTION LIST

NDEP DOCUMENT REVIEW SHEET 


\section{TABLE OF CONTENTS (continued)}

\section{FIGURES}

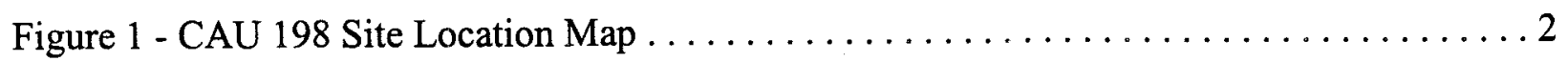

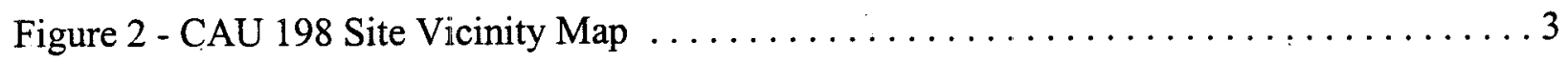

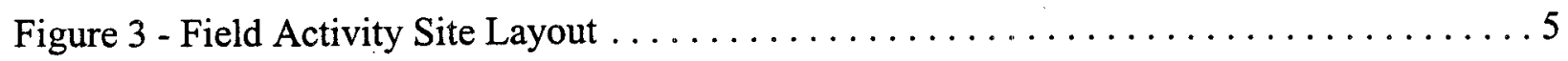

Figure 4 - Post Closure Site Layout $\ldots \ldots \ldots \ldots \ldots \ldots \ldots \ldots \ldots \ldots \ldots \ldots \ldots \ldots \ldots \ldots \ldots \ldots \ldots \ldots \ldots$ 


\section{ACRONYMS AND ABBREVIATIONS}

CAS

CAU

CR

DOE

FFACO

LLW

NDEP

NEPA

NTS

RWAP

RWMS

RWP

SAFER
Corrective Action Site

Corrective Action Unit

Closure Report

U.S. Department of Energy, Nevada Operations Office

Federal Facility Agreement and Consent Order

low-level waste

Nevada Division of Environmental Protection

National Environmental Policy Act

Nevada Test Site

Radioactive Waste Acceptance Program

Radioactive Waste Management Site

Radiological Work Permit

Streamlined Approach for Environmental Restoration 
THIS PAGE INTENTIONALLY LEFT BLANK 


\section{EXECUTIVE SUMMARY}

This plan addresses the closure of Corrective Action Unit (CAU) 198 identified in the Federal Facility Agreement and Consent Order (FFACO). The site is located at the Nevada Test Site (NTS) Area 25 Test Cell C Complex. The CAU consists of one Corrective Action Site (CAS) 25-23-12 which includes two aboveground radioactive wastewater filter tanks.

Closure for this site was completed by the following:

- Excavating into the north side of the soil berm to provide access to the filter tanks.

- Removing, capping, and sealing associated aboveground tank piping.

- Removing the filter tanks from the concrete pad.

- Isolating the filter tanks in a SEALAND ${ }^{\circledR}$ container on-site.

- Transported the tanks to the Area 3 low-level waste Radioactive Waste Management Site at the NTS after receiving Radioactive Waste Acceptance Program approval.

Soils, subsurface piping, and the tanks' concrete support pad were not removed during this field activity. These components of the nuclear furnace test filtration and disposal system were not included in the description of CAU 198 and its associated CAS. These components have been added to the description of CAS 25-02-02 (Test Cell C underground storage tanks) under CAU 168 (six underground wastewater storage tanks) and will be remediated during the closure activities associated with that CAU. The leachfield associated with the system is identified under CAU 267.

Based upon the completion of site activities, it is requested that a notice of completion be provided by the Nevada Division of Environmental Protection for CAU 198. Upon closure approval, CAU 198 will be promoted from Appendix III to Appendix IV of the FFACO, "Closed Corrective Action Units." 
THIS PAGE INTENTIONALLY LEFT BLANK 


\subsection{INTRODUCTION}

This closure report (CR) provides documentation for the closure of Corrective Action Unit (CAU) 198 identified in the Federal Facility Agreement and Consent Order (FFACO). The site is located at the Nevada Test Site (NTS) Area 25 Test Cell C Complex (Figure 1). The CAU consists of one Corrective Action Site (CAS) 25-23-12 which includes two aboveground radioactive wastewater filter tanks used during the Nuclear Furnace Testing at Test Cell C.

The Test Cell $\mathrm{C}$ complex was one of several facilities dedicated to the development of nuclear rocket technology. Test Cell $\mathrm{C}$ was designed to test nuclear rocket reactors. Part of the testing program included Nuclear Furnace Tests. The Nuclear Furnace was a water-moderated, hydrogen-cooled, 44-megawatt reactor used to test fuel elements for the nuclear rocket engine. The Nuclear Furnace in itself was not a nuclear rocket engine.

During testing, hydrogen exited the reactor at a temperature of 2,440 degrees Kelvin. Water was injected into the gas stream to cool the hydrogen and capture the various radiological isotopes. Hydrogen gas effluent was decontaminated through a multistage process before being burned at the Test Cell $\mathrm{C}$ flare stack. A by-product of the decontamination process produced water contaminated with mixed fission products. Prior to discharge to a tile drain system (CAU 267) the water was filtered through the two 2271-liters (600-gallon) filter tanks (Department of Energy [DOE], 1998). Reactor development, engine testing, and rocket development activities were ended in the early 1970s. The filter tanks have remained inactive since that time. The site is currently roped off and posted with "Caution Radiation Area" signs. The filter tanks were located on the east side of Test Cell C, approximately 15.2 meters ( 50 feet) from the facility fence line (Figure 2).

\subsection{PURPOSE}

The purpose of this CR is to:

- Document the closure activities as proposed in the Streamlined Approach for Environmental Restoration (SAFER) Closure Plan (DOE, 1998).

- Obtain a Notice of Completion from the Nevada Division of Environmental Protection (NDEP).

- Recommend the movement of CAU 198 from Appendix III to Appendix IV of the FFACO.

\subsection{SCOPE}

The following is the scope of the closure actions implemented for CAU 198: 


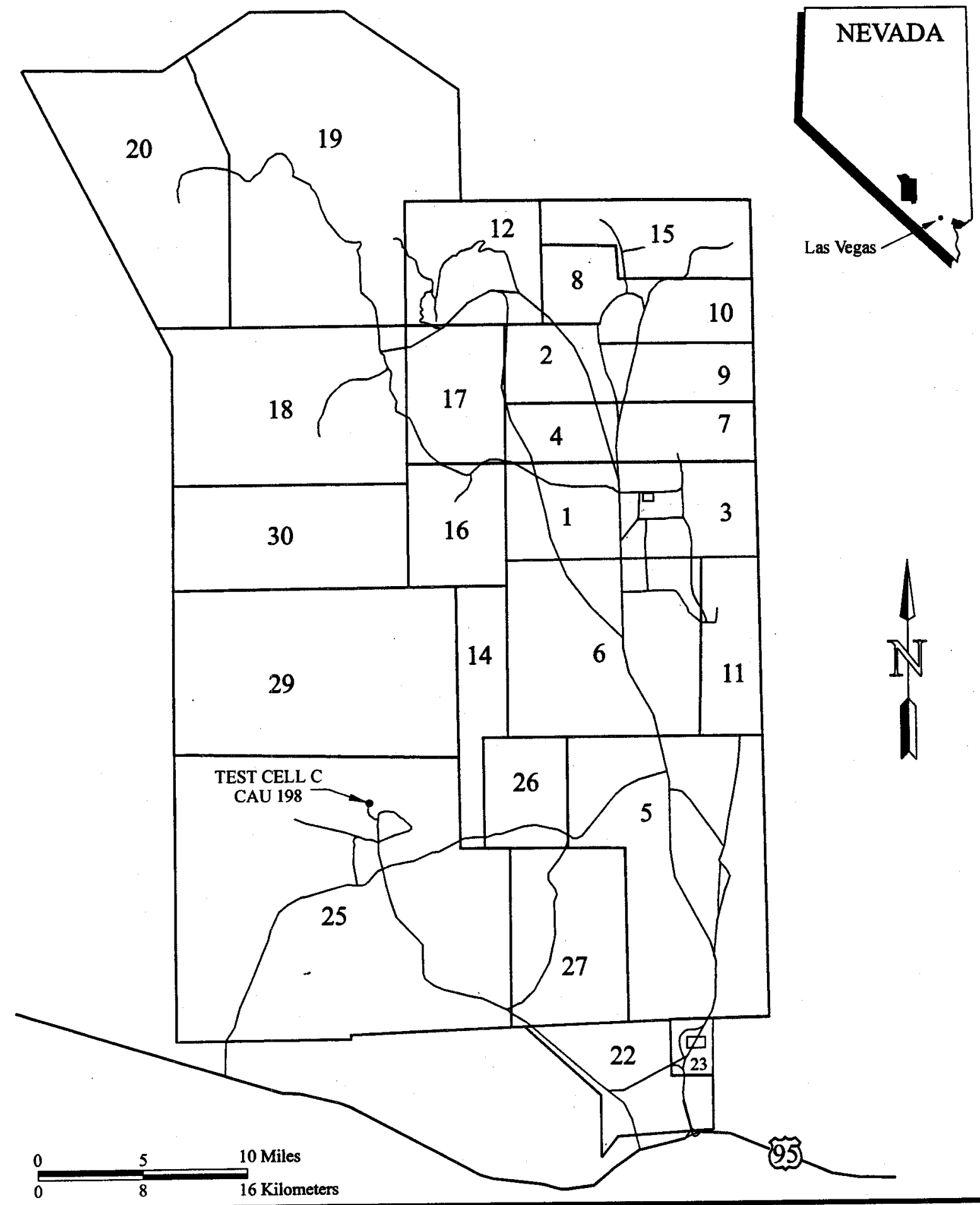

FIGURE 1

CAU 198 SITE LOCATION MAP 


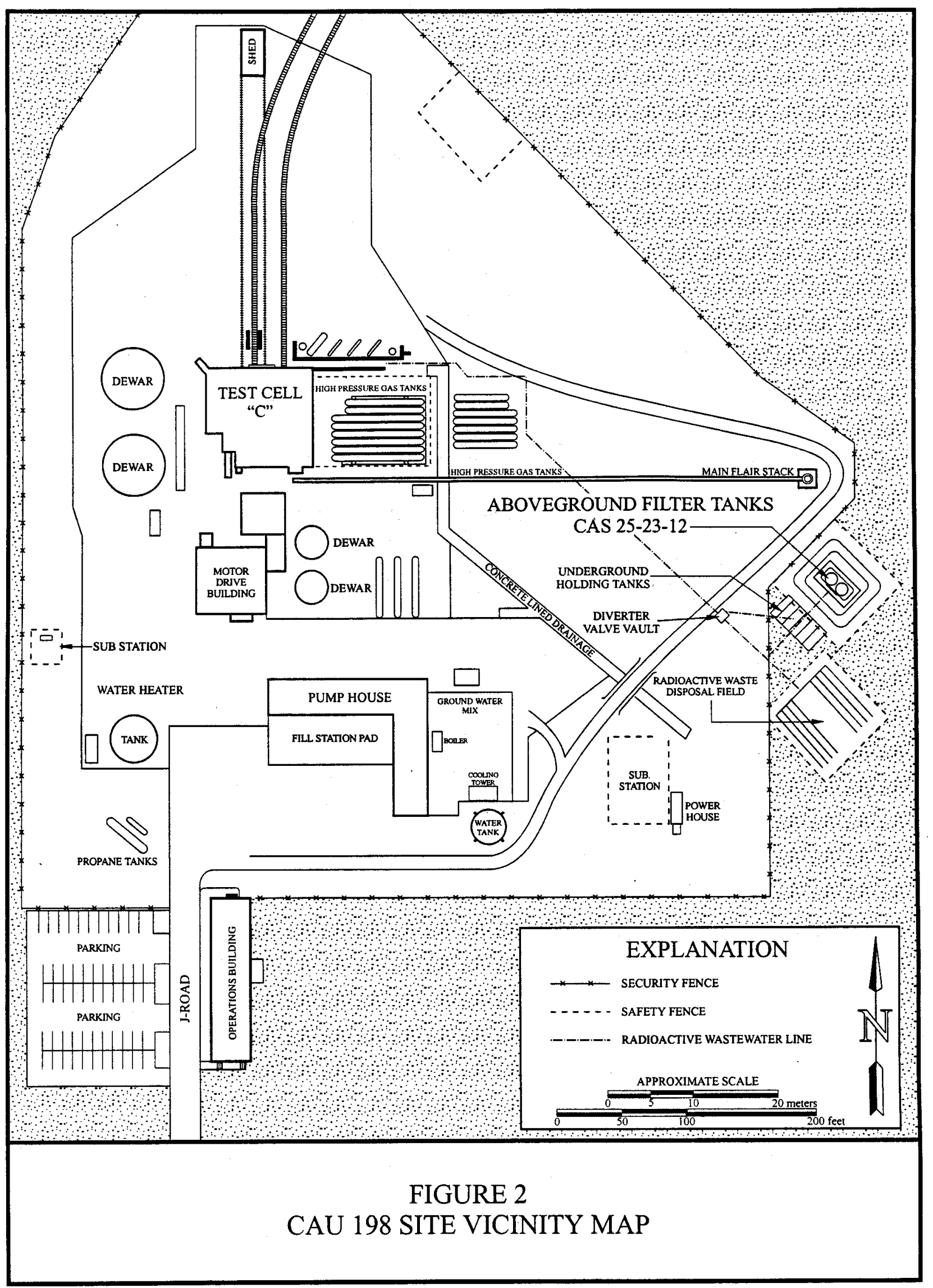


- Excavated the north side of the soil berm to provide access to the filter tanks (Figure 3).

- Cut, removed, and capped the inlet and outlet piping on the tanks.

- Removed the filter tanks from the concrete pad.

- Isolated the filter tanks and associated piping in a SEALAND ${ }^{\circledR}$ container on-site.

- Replaced the excavated berm material.

- Transported the tanks to the Area 3 low-level waste (LLW) Radioactive Waste Management Site (RWMS) at the NTS after receiving Radioactive Waste Acceptance Program (RWAP) approval.

Closure of CAU 198 was completed using the SAFER Plan, Revision 1, dated July 1998 (DOE, 1998). This SAFER closure was based on a radiological site demarcation survey taken February 15, 1996, a prefield activity survey completed on March 31,1998, and process knowledge of the tanks' historical use (DOE, 1998). Gamma spectroscopy measurements were taken on July 22, 1998, and indicated that the tanks contain ${ }^{137}$ Cesium (Appendix A). Cesium is a common radioisotope associated with nuclear reactor testing.

Soils, subsurface piping, and the tanks' concrete support pad were not removed during this field activity. These components of the nuclear furnace test filtration and disposal system were not included in the description of CAU 198 and its associated CAS. These components have been added to the description of CAS 25-02-02 (Test Cell C underground storage tanks) under CAU 168 (six underground wastewater storage tanks) and will be remediated during the closure activities associated with that CAU. The leachfield associated with the system is identified under CAU 267.

\subsection{CONTENTS}

This CR is divided into the following sections:

- Section 1.0 - Introduction

- Section 2.0 - Closure Activities

- Section 3.0 - Waste Disposition

- Section 4.0 - Closure Verification Results

- Section 5.0 - Conclusions and Recommendations 


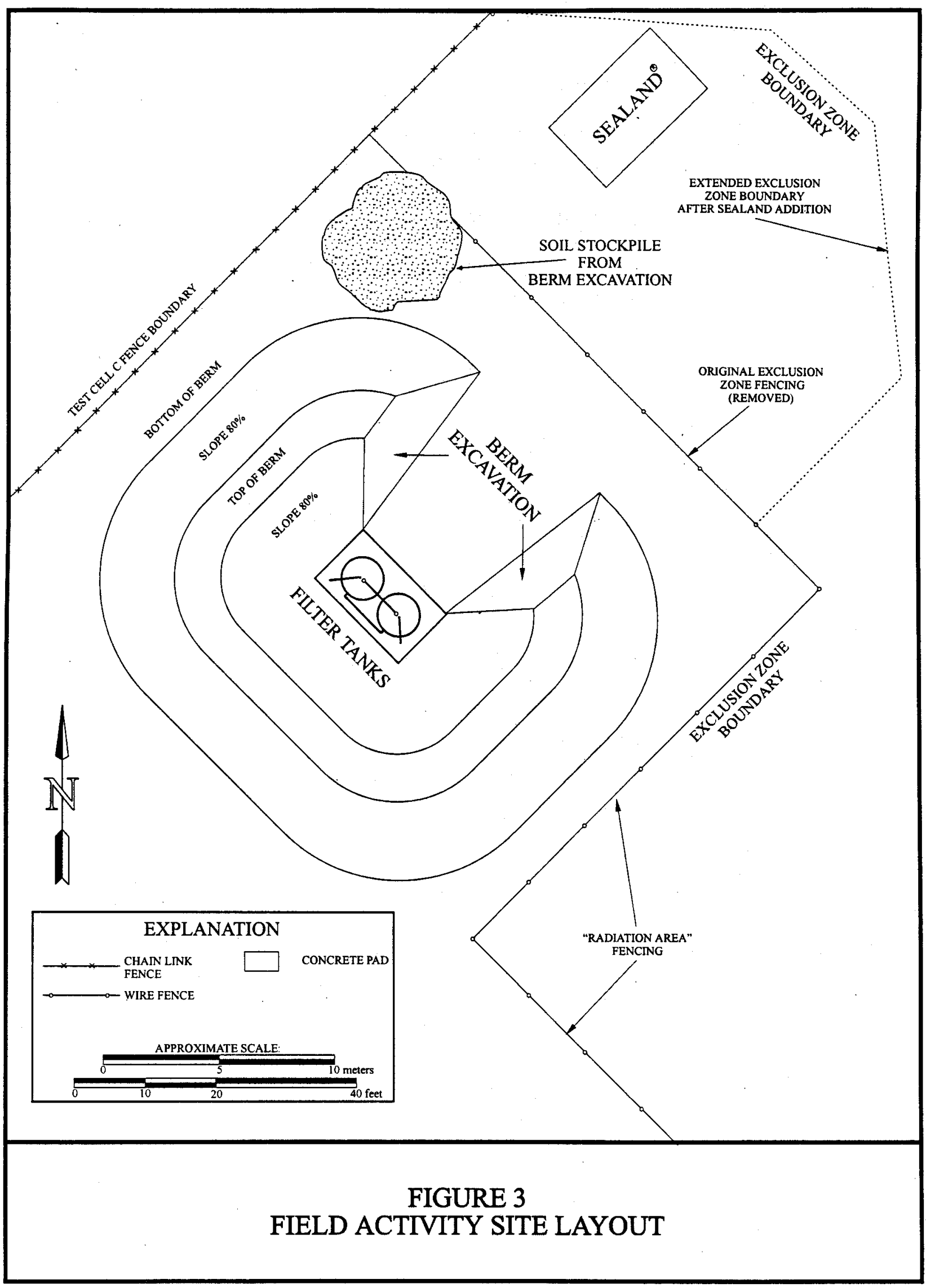


- Section 6.0-References

This report was developed using information and guidance from the following documents:

- Streamlined Approach for Environmental Restoration Work Plan for Corrective Action Unit 198: Test Cell C Eilter Tank Closure Nevada Test Site, Nevada DOE, 1998.

- Nevada Environmental Restoration Project, Health and Safety Plan, Revision 2, DOE, 1996.

- Nevada Environmental Restoration Project, Industrial Sites, Quality Assurance Project Plan, Nevada Test Site, Revision 1, DOE, 1996.

- Nevada Environmental Restoration Project, Project Management Plan, Revision 0, DOE, 1994. 


\subsection{CLOSURE ACTIVITIES}

This section of the CR details the specific activities involved in the closure of the Test Cell C Filter Tanks CAU 198 (CAS 25-23-12).

\subsection{DESCRIPTION OF CORRECTIVE ACTION ACTIVITIES}

Before field activities began, the following prefield activities were completed:

- Preparation of National Environmental Policy Act documentation.

- Preparation of the Site-Specific Health \& Safety Plan.

- Preparation of the Field Management Plan.

- An As Low As Reasonably Achievable Committee review of the proposed activities.

The field activities included two pre-work radiation surveys and removal of the tanks. The first pre-work radiation survey was completed on March 31, 1998, under Radiological Work Permit (RWP) No. 98066. This survey was performed to identify whether radioactivity was removable and where elevated readings were located on the tanks. Soil samples were also taken from the soil berm on the north interior and exterior where the berm was breached for access as well as the soil area surrounding the concrete tank support pad (DOE, 1998). The second pre-work radiation survey was completed on July 22, 1998, under RWP No. 98066. This survey was performed to estimate the activity level and isotopes of concern using a gamma spectroscopy unit. The results of the gamma spectroscopy survey are provided in Appendix A. Site remediation activities included the following:

- Excavating into the north side of the soil berm to provide access to the filter tanks.

- Removing, capping, and sealing associated aboveground tank piping.

- Removing the filter tanks from the concrete pad.

- Isolating the filter tanks and associated piping in a SEALAND ${ }^{\circledR}$ container on-site.

- Transporting the tanks to Area 3 LLW RWMS at the NTS after receiving RWAP approval. 


\subsection{DEVIATIONS FROM SAFER CLOSURE PLAN AS APPROVED}

There were no deviations from the approved SAFER Work Plan (DOE, 1998).

\subsection{CORRECTIVE ACTION SCHEDULE AS COMPLETED}

The corrective action activities were completed in a timely manner. Two pre-work surveys were conducted. The first on March 31, 1998, and the second on July 22, 1998. The March 31, 1998, radiation survey results are provided in DOE 1998 and the July 22, 1998, results are provided in Appendix A.

Field activities were started on August 17, 1998. Tank removal was completed on August 19,1998 . The SEALAND ${ }^{\circledast}$ container, filter tanks, piping, and personal protective equipment was disposed of in the Area 3 LLW RWMS on November 19, 1998 after RWAP approval was given.

\subsection{SITE PLAN}

Figure 2 provides the location of CAU 198, and Figure 3 depicts the site layout. Figure 4 provides the site layout and demarcation postings following the removal of the filter tanks. 


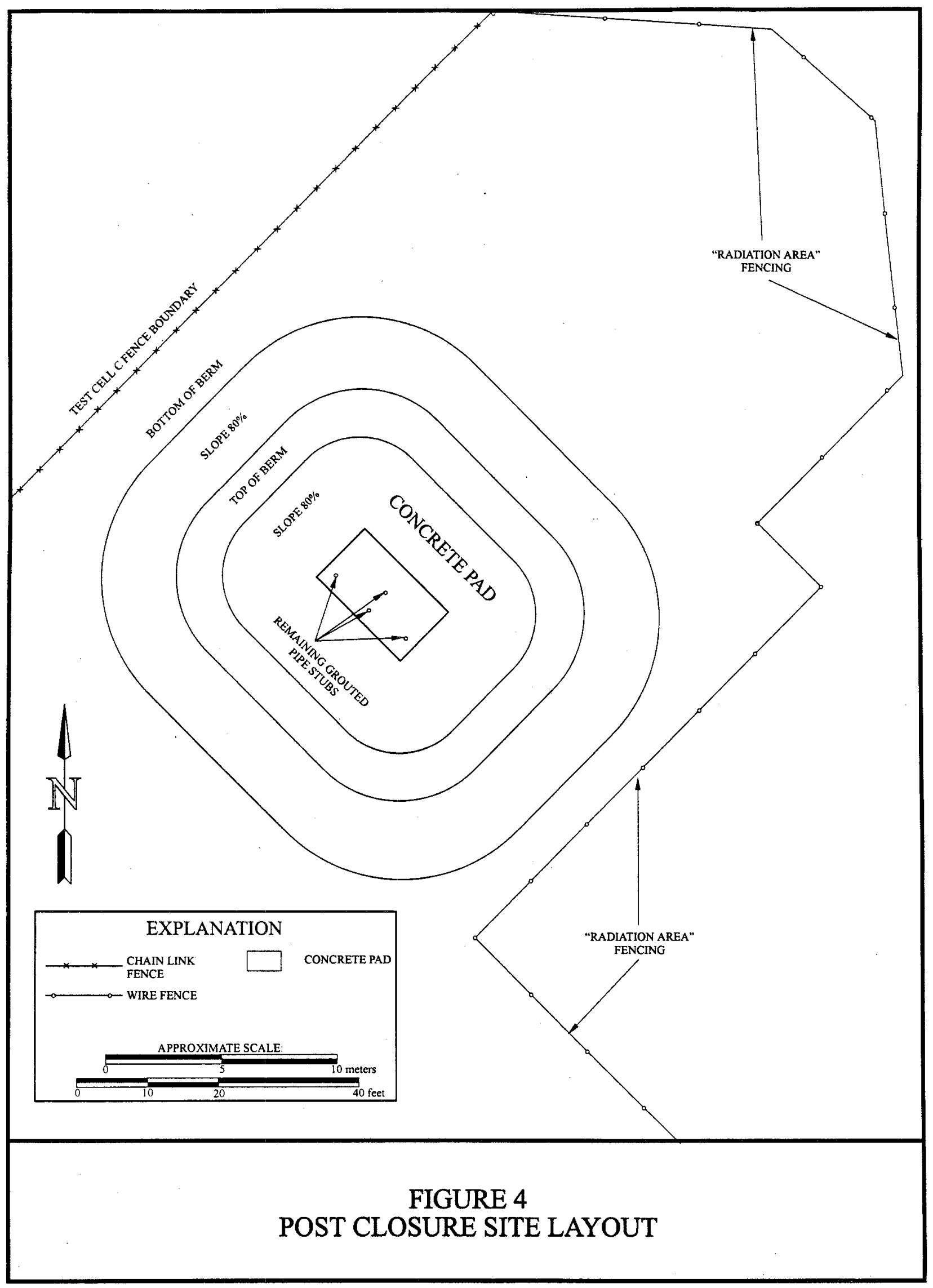




\subsection{WASTE DISPOSITION}

Waste generated from CAU 198 closure activities consisted of radiologically impacted filter tanks and piping, personal protective equipment, and sanitary trash. After RWAP approval the filter tanks, piping, and personal protective equipment were disposed of at the Area 3 RWMS (an approved LLW repository at the NTS) on November 19, 1998. All sanitary trash was containerized and disposed of as sanitary waste. 


\subsection{CLOSURE VERIFICATION RESULTS}

This CAU 198 was closed by complete removal of the filter tanks and aboveground piping. Verification sampling was not required. Tank disposal was based upon process knowledge and data collected from the pre-field surveys.

\subsection{LAND-USE RESTRICTIONS}

The future use of any land related to CAU 198 is not restricted because the filter tanks have been removed. However, the site still retains radiological postings and fencing due to the presence of CAUs 168 and 267. This radiological demarcation restricts access to the site without proper authority. 


\subsection{CONCLUSIONS AND RECOMMENDATIONS}

\subsection{CONCLUSIONS}

Closure for this site was completed by the following:

- Excavating into the north side of the soil berm to provide access to the filter tanks.

- Removing, capping, and sealing associated aboveground tank piping.

- Removing the filter tanks from the concrete pad.

- Isolating the filter tanks in a SEALAND ${ }^{\circledR}$ container on-site.

- Transporting the tanks to the Area 3 LLW RWMS at the NTS after the approval of the RWAP.

\subsection{RECOMMENDATIONS}

Based upon the completion of site activities, it is requested that a notice of completion be provided by the NDEP for CAU 198. Upon closure approval, CAU 198 will be promoted from Appendix III to Appendix IV of the FFACO, "Closed Corrective Action Units." 


\subsection{REFERENCES}

DOE, 1998, Streamlined Approach for Environmental Restoration Work Plan for Corrective Action Unit 198: Test Cell C Filter Tank Closure Nevada Test Site, Nevada, Revision 1, DOE/NV-11718-220, UC-702.

DOE, 1996a, Nevada Environmental Restoration Project, Health and Safety Plan, Revision 2.

DOE, 1996b, Nevada Environmental Restoration Project, Industrial Sites, Quality Assurance Project Plan, Nevada Test Site, Revision 1.

DOE, 1994, Nevada Environmental Restoration Project, Project Management Plan, Revision 0. 
THIS PAGE LEFT INTENTIONALLY BLANK 


\section{APPENDIX A}

\section{RESULTS OF GAMMA SPECTROMETER SURVEY}




\section{Bechtel Nevada}

Interoffice Memorandum $\therefore$

To: $\quad$ S. L. Alderson

From:
A. E. Proctor

Radiation Sciences, 5-8764
Date: August 13, 1998

No.: $2231-\mathrm{HC}-98-0029$

\section{Subject: RESULTS OF MEASUREMENTS ON THE AREA 25 FILTER TANKS}

Gamma spectroscopy measurements were made on filter tanks at Area 25 at several locations on the berm surrounding the tank. Results of these measurements show substantial ${ }^{137} \mathrm{Cs}$ contamination on the tanks and in the surrounding ground. No other radionuclides were found, based on these measurements. A high count rate in the continuum of the spectral data was noted; this suggested that radiation is being scattered before reaching the detector. (As might be expected from buried or shielded sources).

Measurements were made using a high resolution (HPGe) detector housed in a steel collimator. Eight 300-second measurements were made around the tanks and one background measurement was done after returning to the RSL, to check for contamination on the collimator. (None were found).

Relative levels of ${ }^{137} \mathrm{Cs}$ are shown in the table below. Locations are shown as an angle, relative to the entry through the fence. Measurements of the tanks are designated as "s.." ; measurements with the collimator aimed at the berm are designated as "down..". Details of the locations are shown on the attached sketch.

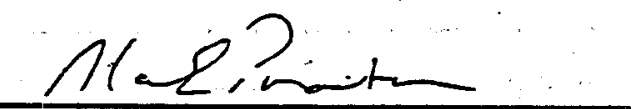

A. E. Proctor

vlb

Subject Code: ENV 4 (External)

cc: Correspondence Control, w/encs., NLV008

H. W. Clark, w/encs., RSL-20

S. R. Riedhauser, w/encs., RSL-24

K. R. Roesner, w/encs., RSL-20 


\section{S.L. Alderson}

Page 2 of 3

August 13, 1998

\begin{tabular}{|l|l|l|}
\hline \multicolumn{2}{|c|}{ Area 25 Filter Tank Measurement Results } \\
\hline Location & *Net 137 Cs rate & $\begin{array}{l}\text { Spectral peak } \\
\text { location }(\mathrm{keV}) ;(137 \mathrm{Cs} \\
\text { peak at } 661.59 \mathrm{keV})\end{array}$ \\
\hline $\begin{array}{l}\text { Downward view, } 270^{\circ} \text { from } \\
\text { entry }\end{array}$ & $1697 \pm 286$ & 663.94 \\
\hline Downward view, $45^{\circ}$ from entry & $2846 \pm 158$ & 663.45 \\
\hline Downward view, $90^{\circ}$ from entry & $2524 \pm 147$ & 663.24 \\
\hline $\begin{array}{l}\text { Viewing both tanks, } 0^{\circ} \text { from } \\
\text { entry }\end{array}$ & $30702 \pm 614$ & 659.99 \\
\hline $\begin{array}{l}\text { Viewing both tanks, } 180^{\circ} \text { from } \\
\text { entry }\end{array}$ & $19470 \pm 389$ & 664.10 \\
\hline $\begin{array}{l}\text { Viewing tank "A", } 270^{\circ} \text { from } \\
\text { entry }\end{array}$ & $20176 \pm 461$ & 663.87 \\
\hline $\begin{array}{l}\text { Viewing tank "B", } 270^{\circ} \text { from } \\
\text { entry }\end{array}$ & $33076 \pm 383$ & 663.91 \\
\hline $\begin{array}{l}\text { Viewing both tanks, } 90^{\circ} \text { from } \\
\text { entry }\end{array}$ & $32936 \pm 345$ & 659.23 \\
\hline $\begin{array}{l}\text { Background at RSL after } \\
\text { measurements }\end{array}$ & $* * 0.0$ & -- \\
\hline
\end{tabular}

Highest rates were seen nearest the fence entry, around the " $B$ tank", viewing in both directions. This suggests that the " $\mathrm{B}$ " tank has higher levels of contamination.

* Units are counts per second at the photo peak (confirmed with A. E. Proctor by phone on December 22, 1998).

** Measurement conducted at the Remote Sensing Lab after the field survey to detect contamination on the equipment (confirmed with A. E. Proctor by phone on December 22, 1998). 
2231-HC-98-0029

S. L. Alderson

Page 3 of 3

August 13, 1998

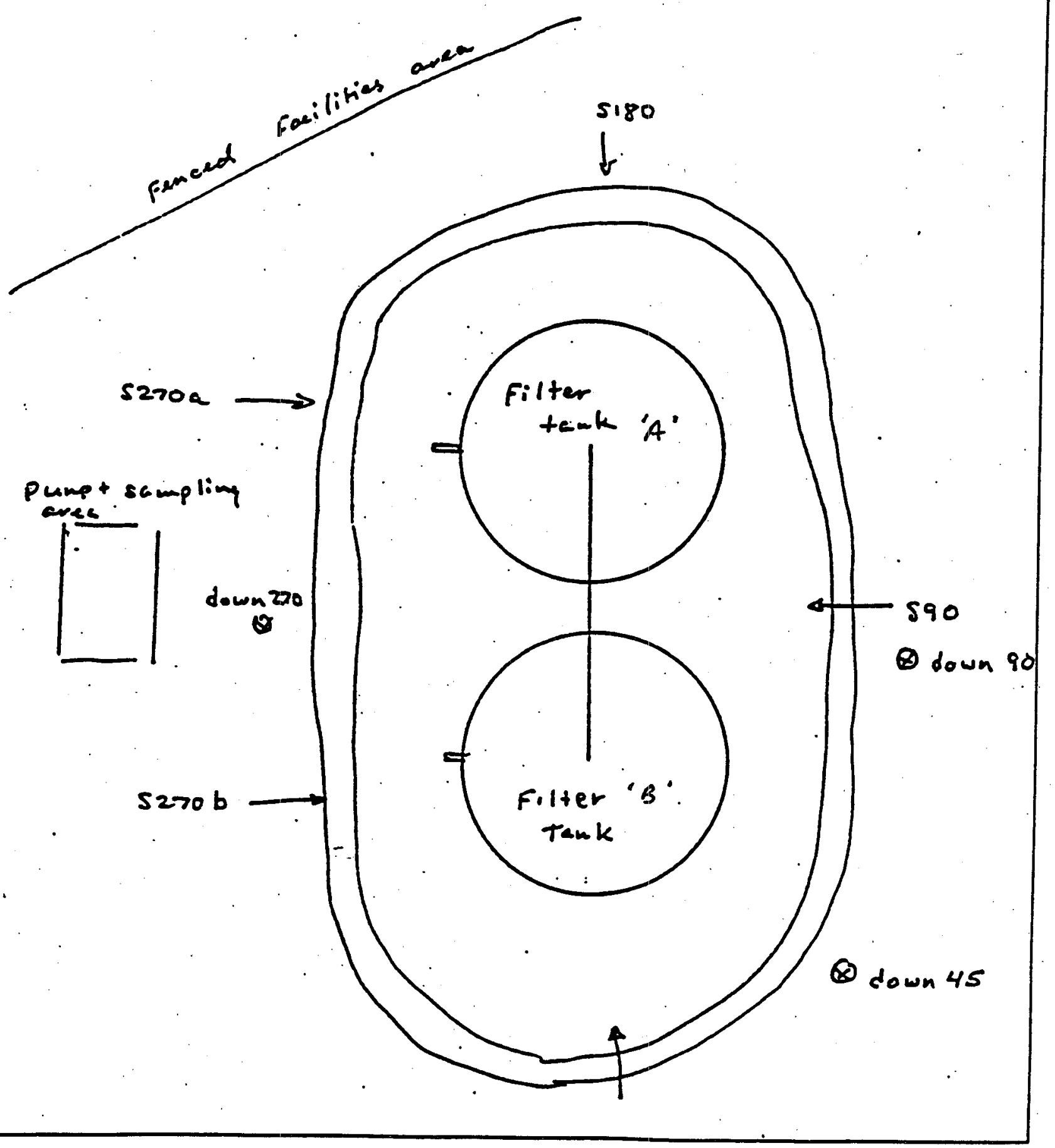




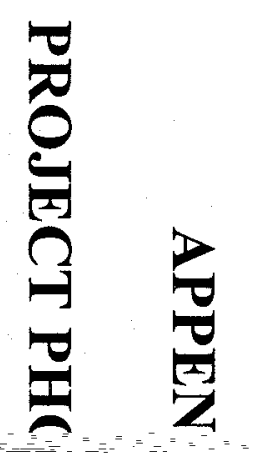

$=$ 更 更 2 $=0$ (1) 作

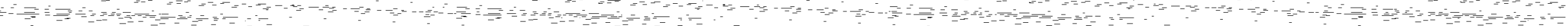

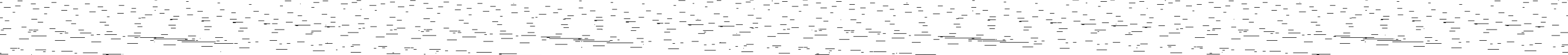




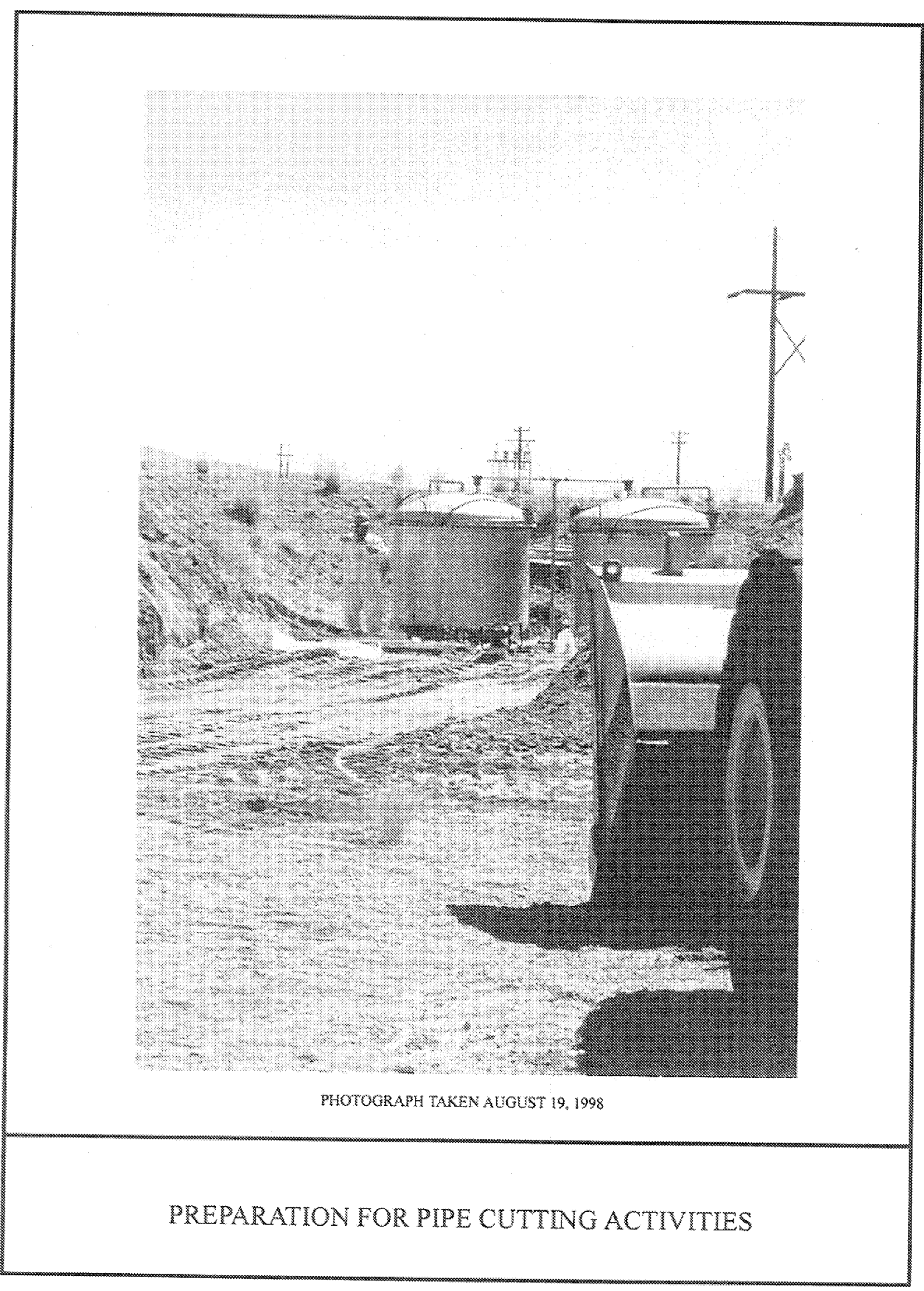




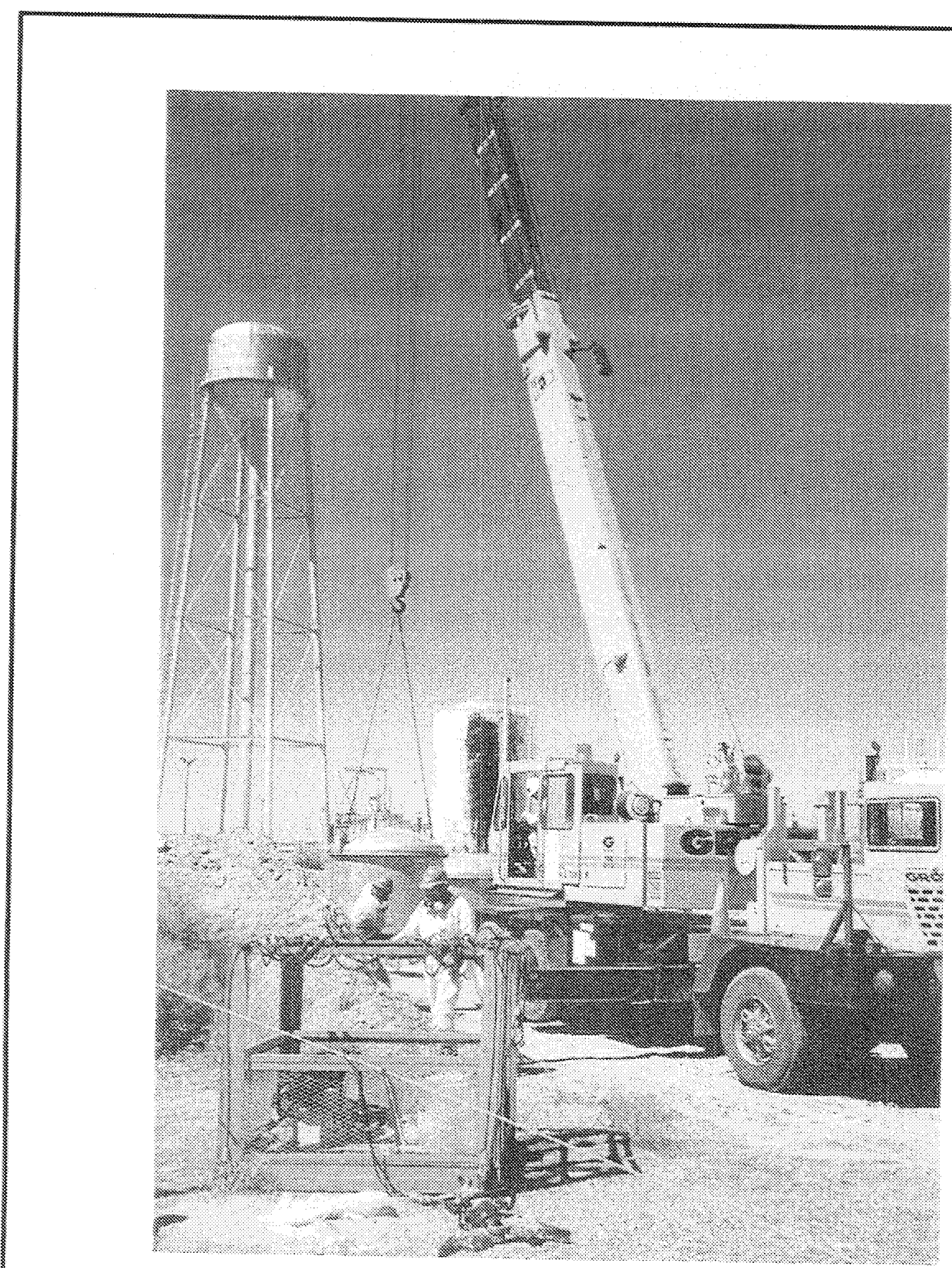

PXOTOGRAYH TAKEN ACGUST 19, 1996

REMOVING TANK FROM CONCRETE PAD 


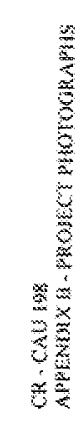

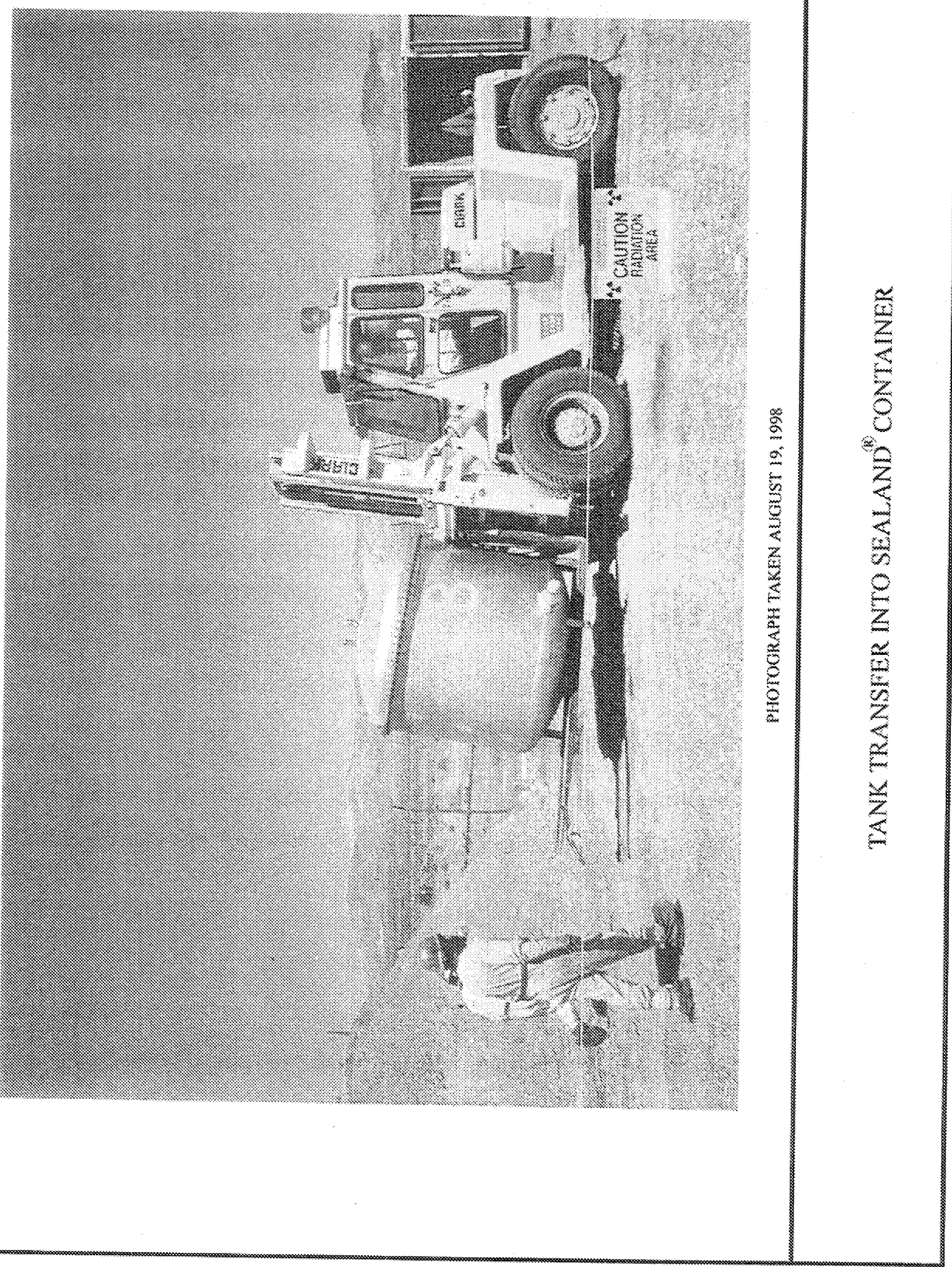




\section{APPENDIX C}

TEST CELL C FILTER TANK DISPOSAL VERIFICATION LETTER 
Interoffice Memorandum

To: J. F. Bonn

From: $\quad$ S. L. Alderson

Waste Management Department, 295-4811
Date: November 23, 1998

No.: 2151-SA-98-0010

\section{Subject: DISPOSAL OF LRY5-LLFY98013 AREA 25 TEST CELL C FILTER TANKS \\ Project No. 04008}

This is notification that on November 19,1998 , the subject waste stream was succesfully shipped from Area 25 to the Area 3 Radioactive Waste Management Site (RWMS) for disposal. Attached are three documents indicating that the material was recieved by the RWMS and disposed. The document descriptions are as follows:

Attachement titled MEF DETAIl REPORT, this is a copy of the Waste Minimization and Control Projects (WM\&CP) waste tracking database entry for LRY5-LLFY98013. This report provides information on the waste stream

Attachment titled DISPOSAL SHIPMENT REPORT, this is a copy of the WM\&CP's waste tracking databse shipment report. This report provides information on the package(s) shipped under the Waste Stream ID (WSID) Number LRY5-LLFY98013 for disposal.

Attachment titled, Waste Management System, this is a copy of the notification and reciept of waste shipment number DPL99001 to the Area 3 RWMS.

If you have any questions, please call me at 295-4811, M/S NTS110.

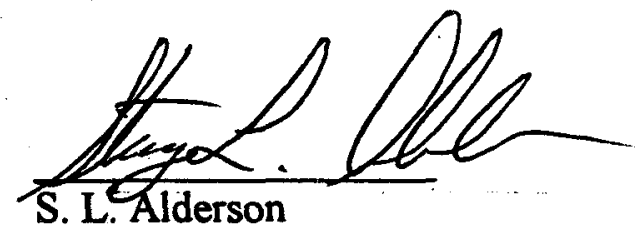

SLA:lad

Subject Code: WMT17

Enclosure: as stated

ce w/enc.

Correspondence Control, NLV008

P. M. Ralphs, NTS330

cew/o enc.

S. L. Alderson, NTS 110

J. L. Cowley, NTS110

D. K. Cowser, NLV082

J. A. Dickinson, NLV080

L. A. Dunn, NTS110

S. J. Nacht, NTS306 


\section{DISTRIBUTION LIST}




\section{DISTRIBUTION LIST}

*Provide copy of initial distribution of Revision 0; remainder of list gets Revision 0 if approved without changes. The entire list receives Revision 1, if issued.

\section{Nevada Department of Environmental Protection}

Paul Liebendorfer

Bureau of Federal Facilities

Division of Environmental Protection

333 W. Nye Lane, Room 13B

Carson City, NV 89706-0866

Michael D. McKinnon

Bureau of Federal Facilities

Division of Environmental Protection

555 E. Washington, Suite 4300

Las Vegas, NV 89010

\section{U.S. Department of Energy}

Janet Appenzeller-Wing

Environmental Restoration Division

U.S. Department of Energy, Nevada Operations Office

P.O. Box $98518 \mathrm{M} / \mathrm{S} 505$

Las Vegas, NV 89193-8518

Clayton W. Barrow

Environmental Restoration Division

U.S. Department of Energy, Nevada Operations Office

P.O. Box $98518 \mathrm{M} / \mathrm{S} 505$

Las Vegas, NV 89193-8518

Sabrina Lawrence

Environmental Restoration Division

U.S. Department of Energy, Nevada Operations Office

P.O. Box $98518 \mathrm{M} / \mathrm{S} 505$

Las Vegas, NV 89193-8518

DOE Public Reading Facility

P.O. Box $98521 \mathrm{M} / \mathrm{S}$ NLV040

Las Vegas, NV 89193-8521
2 (Controlled)*

1 (Controlled)*

1 (Uncontrolled)*

1 (Uncontrolled)*

1 (Controlled)* $^{*}$

1 (Controlled) 


\section{DISTRIBUTION LIST (Continued)}

DOE/Nevada Operations Office

1 (Uncontrolled)

Technical Information Resource Center

P.O. Box $98521 \mathrm{M} / \mathrm{S} 505$

Las Vegas, NV 89193-8521

U.S. Department of Energy

2 (Uncontrolled)

Office of Scientific and Technical Information

175 Oak Ridge Turnpike

P.O. Box 62

Oak Ridge, TN 37831

\section{Bechtel Nevada}

Correspondence Control

1 (Uncontrolled)*

Bechtel Nevada

P.O. Box $98521 \mathrm{M} / \mathrm{S}$ NLV008

Las Vegas, NV 89193-8521

Environmental Management Correspondence Control

1 (Uncontrolled)*

Bechtel Nevada

P.O. Box $98521 \mathrm{M} / \mathrm{S}$ NLV080

Las Vegas, NV 89193-8521

Jerry Bonn

1 (Uncontrolled)*

Bechtel Nevada

P.O. Box $98521 \mathrm{M} / \mathrm{S}$ NTS306

Las Vegas, NV 89193-8521

Janet Cowley

Bechtel Nevada

1 (Uncontrolled)

P.O. Box $98521 \mathrm{M} / \mathrm{S}$ NTS1 10

Las Vegas, NV 89193-8521

David Cowser

1 (Uncontrolled)*

Bechtel Nevada

P.O. Box $98521 \mathrm{M} / \mathrm{S}$ NLV082

Las Vegas, NV 89193-8521

Thomas Fitzmaurice

1 (Uncontrolled)*

Bechtel Nevada

P.O. Box $98521 \mathrm{M} / \mathrm{S}$ NTS306

Las Vegas, NV 89193-8521 


\section{DISTRIBUTION LIST (Continued)}

Steve Nacht

Bechtel Nevada

P.O. Box $98521 \mathrm{M} / \mathrm{S}$ NTS306

Las Vegas, NV 89193-8521
1 (Uncontrolled)* 
NDEP DOCUMENT REVIEW SHEET 


\section{DOCUMENT REVIEW SHEET}

Document Title/Number: Draft Streamlined Approach for Environmental Restoration Closure Report for Corrective Action Unit 198: Test Cell C Filter Tank Closure, the Nevada Test Site, Nevada/DOE/NV/11718--259

Document Date: September 1998

Revision Number: 0

Originator/Organization: Thomas Fitzmaurice, Bechtel Nevada Environmental Restoration

Date Comments Due: November 1, 1998

Reviewer/Organization: Michael McKinnon, Supervisor, Nevada Division of Environmental Protection

\begin{tabular}{||c|c|c|c||}
\hline \hline $\begin{array}{c}\text { Comment } \\
\text { Number/ } \\
\text { Location }\end{array}$ & Type $^{\mathbf{a}}$ & Comment & Comment Response \\
\hline $\begin{array}{c}\text { Page vii, } \\
\text { Abstract }\end{array}$ & $\mathrm{M}$ & $\begin{array}{l}\text { According to the SAFER Work Plan, July } \\
\text { 1998, the removed tanks will be transported } \\
\text { to an approved low-level waste repository at } \\
\text { NTS pending RWAP approval. What is the } \\
\text { current disposition of the tanks? }\end{array}$ & $\begin{array}{l}\text { RWAP approval was received on } \\
\text { October 13, 1998. The filter tanks were } \\
\text { subsequently transported to the Area 3 } \\
\text { RWMS (November 19, 1998). This final } \\
\text { SAFER Closure Report has been } \\
\text { amended to reflect the new status of the } \\
\text { filter tanks. }\end{array}$ \\
\hline
\end{tabular}




\section{DOCUMENT REVIEW SHEET}

\begin{tabular}{||c|c|l|l|l||}
\hline $\begin{array}{c}\text { Comment } \\
\text { Number/ } \\
\text { Location }\end{array}$ & Type & Comment & Comment Response & Accept \\
\hline $\begin{array}{c}\text { Page vii, } \\
\text { Abstract }\end{array}$ & $\mathrm{M}$ & $\begin{array}{l}\text { The soils, subsurface piping, concrete } \\
\text { support pad and radioactive leachfield which } \\
\text { were not remediated in this SAFER process } \\
\text { must be identified with another Corrective } \\
\text { Action Unit (CAU). A formal request must } \\
\text { be presented to NDEP to accomplish this } \\
\text { action and must be addressed at the next } \\
\text { Federal Facilities Agreement and Consent } \\
\text { Order (FFACO) quarterly meeting. }\end{array}$ & $\begin{array}{l}\text { According to a letter received from Pam } \\
\text { Adams of IT Corporation (December } \\
\text { 14/98) the subsurface piping and concrete } \\
\text { were incorporated with CAU 168 and } \\
\text { approved by letter from the NDEP dated } \\
\text { August 31, 1998. The radioactive } \\
\text { leachfield is identified under CAU 267 } \\
\text { according to the FFACO. The Final } \\
\text { SAFER Closure Report reflects the } \\
\text { CAU/CAS designations. }\end{array}$ & Yes \\
\hline $\begin{array}{c}\text { Appendix A } \\
\text { Gamma } \\
\text { Spectrometer } \\
\text { Results }\end{array}$ & $\mathrm{M}$ & $\begin{array}{l}\text { What are the units for the Cs-137 results? } \\
\text { Also, a "zero" result for gamma background } \\
\text { is questionable. }\end{array}$ & $\begin{array}{l}\text { The units are counts per second at the } \\
\text { photo peak. The zero result recorded for } \\
\text { background was a measurement } \\
\text { conducted at the Remote Sensing Lab } \\
\text { after the field survey to detect } \\
\text { contamination on the equipment. The } \\
\text { zero results indicates that there was no } \\
\text { contamination. Appendix A has been } \\
\text { amended to reflect this information. }\end{array}$ & Yes \\
\hline
\end{tabular}

